\title{
Schoolchildren Survey and Community Survey for The Determination of Seroprevalence Against IgM Anti Phenolic Glycolipid-I Antibody in Leprosy Endemic Areas, South Sulawesi, Indonesia
}

\section{A Comparative Study}

\author{
Mochammad Hatta
}

\begin{abstract}
Abstrak
Pada penelitian ini dilaporkan tentang kegunaan IgM anti phenolic glycolipid-I (PGL-I) dengan menggunakan tes Mycobacterium leprae particle agglutination (MLPA) pada survei anak sekolah yang dibandingkan dengan survei penduduk pada daerah endemik lepra di Indonesia. Dua desa dengan jumlah keseluruhan registrasi penduduk masing-masing 1729 dan 3077 orang dipilih untuk menentukan seroprevalensi pada tiap desa tersebut. Dari 510 dan 1496 orang yang diperiksa, ditemukan $18.4 \%$ dan $40.4 \%$ seropositif antibodi IgM terhadap PGL-I. Delapan puluh dan 44 anak sekolah dari dua desa yang sama diperiksa dan ditemukan masing-masing $17.6 \%$ dan $40.9 \%$ seropositif. Tidak ada perbedaan yang bermakna dalam seroprevalensi antara anak sekolah dan jumlah keseluruhan penduduk yang diperiksa dari masing-masing desa. Sebagai kesimpulan ialah survei anak sekolah berguna untuk menentukan seroprevalensi terhadap infeksi lepra dan menggambarkan besarnya seroprevalensi populasi penduduk pada tingkat desa.
\end{abstract}

\begin{abstract}
This study reports on the usefulness of IgM anti phenolic glycolipid-1 (PGL-I) antibody detection using Mycobacterium leprae particle agglutination (MLPA) test in a schoolchildren survey compared with a community survey in leprosy endemic areas, Indonesia. Two villages with total registered persons 1729 and 3077 respectively were chosen to determine the seroprevalence of each village. Among 510 and 1496 examined persons in a population survey it tumed out that $18.4 \%$ and $40.4 \%$ respectively were seropositive to IgM anti PGL-I antibody. In 80 and 44 examined schoolchildren of the same respective areas $17.6 \%$ and $40.9 \%$ were found seropositive. No significant difference on seroprevalence was found between schoolchildren and community survey in each village. In conclusion, schoolchildren survey may be useful in determining the seroprevalence of leprosy infection and reflect the magnitude of seroprevalence among a population in a leprosy endemic area at village level.
\end{abstract}

Keywords : IgM anti phenolic glycolipid-I, MLPA, Seroprevalence, Leprosy

Leprosy is a chronic infectious disease by Mycobacterium leprae and afflict an estimated 5.5 million people in the world. ${ }^{1} M$. leprae can be identified by the presence of a specific DNA using polymerase chain reaction (PCR) ${ }^{2,3,4}$ and phenolic glycolipid-I (PGL-I) as specific antigen epitope. ${ }^{5}$ PGL-I antigens have been developed as a serological tool for leprosy and Mycobacterium leprae particle agglutination (MLPA) test is a new test using sensitized gelatin particle to detect Ig $\mathrm{M}$ anti PGL-I antibody. ${ }^{6}$

Among the major infectious diseases, leprosy is probably the least well understood as to its epidemiol-

Department of Medical Microbiology, Faculty of Medicine,

Hasanuddin University, Ujung Pandang. Indonesia. $\mathrm{ogy}^{7}$. Our knowledge of the natural history of the disease is also very limited. Previously, the MLPA test has been evaluated as a tool in the epidemiology of leprosy in high prevalence villages in South Sulawesi, Indonesia. Our results revealed that most of the population ever infected by $M$. leprae was $31.9 \%$, i.e. positive for IgM anti PGL-I antibodies. ${ }^{8}$

It is commonly believed that most individuals will become infected by $M$. leprae after sufficient duration of contact with leprosy patients, but it seems that in most cases of infection, symptoms fail to develop. ${ }^{9}$

Furthermore, we examined the distribution and persistence of antibody to PGL-I among individuals in an area in which leprosy is endemic, and no significantly different results were found in seropositivity rates using 
MLPA test or ELISA method during one year observation of the same individuals. ${ }^{10}$

Recently, we conducted an epidemiological survey in South Sulawesi, Indonesia, a well known hyperendemic area of leprosy, to estimate the rate of $M$. leprae infection and to ascertain the possible non human sources of bacilli. The seropositive rates of anti PGL-I antibody in the general inhabitants were about $35 \%$ and $47 \%$ in males and females, respectively. ${ }^{11,12}$ Control of the disease would be facilitated if it were possible to detect individuals with subclinical disease within the next years because of the lack of an appropriate cell-mediated response. Much of the interest in the development of serological tests for leprosy has been carried out with two objectives in mind, and, in particular, attempts have been made to evaluate the usefulness of school children survey compared to community survey in the same area.

The present study is to examine IgM anti PGL-I from school children which is useful for the determination of seroprevalence and reflection of the magnitude of seroprevalence among a population in a leprosy endemic area at village level.

\section{METHODS}

Population study. In 1994, two isolated adjacent villages (Jenetaesa and Tukamasea) in a rural area of South Sulawesi, Indonesia, with 1729 and 3077 inhabitants respectively, were selected for the survey. Persons who had lived in these villages for at least the three months preceding and including the study period were defined as residents. Before the study was undertaken, the individuals of the villages were informed of the purpose of the study, and consent were obtained from all participants.

Three elementary schools in Jenetaesa with 87 registered schoolchildren of grade $\mathrm{V}$ and five elementary schools in Tukamasea with 65 registered schoolchildren of grade $\mathrm{V}$ were included in the study. As it was not feasible to examine all registered persons, we randomized to collect sera of both the community and school children.

We clinically examined 1540 persons in Jenetaesa and 2357 persons in Tukamasea during the community survey. Sera for MLPA were collected from 510 persons in Jenetaesa and 1496 persons in Tukamasea. Sera were collected not of all of clinically examined persons, but only from those who consented to this study. Sera were collected from 80 schoolchildren in Jenetaesa and 44 schoolchildren in Tukamasea for the detection of antibody to PGL- I using MLPA test.
Clinical examination was carried out by experienced leprosy workers and diagnosis was based on the classification of Ridley and Jopling. ${ }^{13}$ Slit skin smears were taken from earlobes and a sample from one lesion at least, from all patients for the determination of bacterial index (BI).

Blood collection. Blood samples were collected by venapuncture $(1.0 \mathrm{ml}$ i.v). Samples were centrifuged at $3000 \mathrm{rpm}$ for 5 minutes to separate the serum and transferred to $500 \mu \mathrm{l}$ vials (Sarsted, Assist Trading Co., Ltd, Japan) on the same day. All sera were stored at $-20^{\circ} \mathrm{C}$ for futher analysis.

The samples collected from individuals were coded, and MLPA test was performed without prior knowledge as to its the classification.

MLPA test. The Serodia-leprae microtitre particle agglutination test kit for the detection of IgM anti PGL-I antibody was purchased from Fujirebio Inc., Japan. ${ }^{6}$

Serum samples were diluted to $1: 16$ and 1:32 in 96 well $\mathrm{U}$ bottom microplates. Twenty five $\mu \mathrm{l}$ of unsensitized gelatin particle and $25 \mu \mathrm{l}$ particle sensitized with trisaccharide of PGL-I (NT-P-BSA) were mixed with $25 \mu$ l of $1: 16$ and $25 \mu 1$ 1:32 diluted samples, respectively. After being incubated for 2 hours at room temperature, the plate was read for agglutination using a mirror reader. Serum samples showing agglutination at a titre of $\geq 1: 32$ were considered positive. When samples were found to agglutinate at $1: 32$, they were then serially diluted to a concentration of $1: 1024$ for quantitative tests.

Data analysis. All data were recorded on special forms and anylized using a database and statistical software package (Epi-Info, version 6) in appropriate hardware. Analysis of variance methods were applied as indicated in the text. All probabilities presented are twotailed.

\section{RESULTS}

Sample size and Incidence rate. At the beginning of the survey 1729 people in Jenetaesa and 3077 people in Tukamasea were registered. A total of 1540 inhabitants ( $89.0 \%$ of registered population) in Jenetaesa and 2357 inhabitants $(68.5 \%$ of registered population) in Tukamasea were clinically examined for signs of leprosy. The age group and sex structure of registered and examined population in two villages were shown in Fig. 1 and Fig. 2, respectively. 
MLPA test or ELISA method during one year observation of the same individuals. ${ }^{10}$

Recently, we conducted an epidemiological survey in South Sulawesi, Indonesia, a well known hyperendemic area of leprosy, to estimate the rate of $M$. leprae infection and to ascertain the possible non human sources of bacilli. The seropositive rates of anti PGL-I antibody in the general inhabitants were about $35 \%$ and $47 \%$ in males and females, respectively. ${ }^{11,12}$ Control of the disease would be facilitated if it were possible to detect individuals with subclinical disease within the next years because of the lack of an appropriate cell-mediated response. Much of the interest in the development of serological tests for leprosy has been carried out with two objectives in mind, and, in particular, attempts have been made to evaluate the usefulness of school children survey compared to community survey in the same area.

The present study is to examine IgM anti PGL-I from school children which is useful for the determination of seroprevalence and reflection of the magnitude of seroprevalence among a population in a leprosy endemic area at village level.

\section{METHODS}

Population study. In 1994, two isolated adjacent villages (Jenetaesa and Tukamasea) in a rural area of South Sulawesi, Indonesia, with 1729 and 3077 inhabitants respectively, were selected for the survey. Persons who had lived in these villages for at least the three months preceding and including the study period were defined as residents. Before the study was undertaken, the individuals of the villages were informed of the purpose of the study, and consent were obtained from all participants.

Three elementary schools in Jenetaesa with 87 registered schoolchildren of grade $\mathrm{V}$ and five elementary schools in Tukamasea with 65 registered schoolchildren of grade $\mathrm{V}$ were included in the study. As it was not feasible to examine all registered persons, we randomized to collect sera of both the community and school children.

We clinically examined 1540 persons in Jenetaesa and 2357 persons in Tukamasea during the community survey. Sera for MLPA were collected from 510 persons in Jenetaesa and 1496 persons in Tukamasea. Sera were collected not of all of clinically examined persons, but only from those who consented to this study. Sera were collected from 80 schoolchildren in Jenetaesa and 44 schoolchildren in Tukamasea for the detection of antibody to PGL- I using MLPA test.
Clinical examination was carried out by experienced leprosy workers and diagnosis was based on the classification of Ridley and Jopling. ${ }^{13}$ Slit skin smears were taken from earlobes and a sample from one lesion at least, from all patients for the determination of bacterial index (BI).

Blood collection. Blood samples were collected by venapuncture $(1.0 \mathrm{ml}$ i.v $)$. Samples were centrifuged at $3000 \mathrm{rpm}$ for 5 minutes to separate the serum and transferred to $500 \mu \mathrm{l}$ vials (Sarsted, Assist Trading Co., Ltd, Japan) on the same day. All sera were stored at $-20^{\circ} \mathrm{C}$ for futher analysis.

The samples collected from individuals were coded, and MLPA test was performed without prior knowledge as to its the classification.

MLPA test. The Serodia-leprae microtitre particle agglutination test kit for the detection of IgM anti PGL-I antibody was purchased from Fujirebio Inc., Japan. $^{6}$

Serum samples were diluted to $1: 16$ and 1:32 in 96 well $\mathrm{U}$ bottom microplates. Twenty five $\mu \mathrm{l}$ of unsensitized gelatin particle and $25 \mu \mathrm{l}$ particle sensitized with trisaccharide of PGL-I (NT-P-BSA) were mixed with $25 \mu 1$ of $1: 16$ and $25 \mu 1$ 1:32 diluted samples, respectively. After being incubated for 2 hours at room temperature, the plate was read for agglutination using a mirror reader. Serum samples showing agglutination at a titre of $\geq 1: 32$ were considered positive. When samples were found to agglutinate at $1: 32$, they were then serially diluted to a concentration of $1: 1024$ for quantitative tests.

Data analysis. All data were recorded on special forms and anylized using a database and statistical software package (Epi-Info, version 6) in appropriate hardware. Analysis of variance methods were applied as indicated in the text. All probabilities presented are twotailed.

\section{RESULTS}

Sample size and Incidence rate. At the beginning of the survey 1729 people in Jenetaesa and 3077 people in Tukamasea were registered. A total of 1540 inhabitants ( $89.0 \%$ of registered population) in Jenetaesa and 2357 inhabitants $(68.5 \%$ of registered population) in Tukamasea were clinically examined for signs of leprosy. The age group and sex structure of registered and examined population in two villages were shown in Fig. 1 and Fig. 2, respectively. 
There was no statistically difference in age group and sex among the registered and examined population in the two villages ( chi-square test with Yate correction, $\mathrm{p}>0.05$ ).

During the survey 20 new leprosy patients in Jenetaesa and 29 new leprosy patients in Tukamasea were found and 8 treated patients ( $3 \mathrm{LL}, 1 \mathrm{BT}$ and $4 \mathrm{TT}$ ) in Jenetaesa and 2 treated patients (2 LL) in Tukamasea had been identified years before by the local health service. The type of leprosy according to Ridley and Jopling classification were 19 tuberculoid type ( 17 TT and $2 \mathrm{BT}$, with $\mathrm{BI}=0$ ) and 1 lepromatous type ( $1 \mathrm{BL}$, with $\mathrm{BI}=3$ ) in Jenetaesa. Twenty seven patients in Tukamasea were classified as tuberculoid ( $3 \mathrm{BT}$ and 24 TT with $\mathrm{BI}=0$ ) and 2 as lepromatous ( $1 \mathrm{LL}$ and 1 $\mathrm{BL}$, with $\mathrm{BI}=4$ and 3 , respectively). Our results showed that the incidence rate of leprosy in the surveyed areas were 12.9/1.000 population in Jenetaesa and $12.3 / 1.000$ population in Tukamasea.

Schoolchildren survey. In the schoolchildren survey 80 from 87 registered schoolchildren in grade V (91.9 $\%$ ) in Jenetaesa ( Fig 3 ) and 44 from 65 registered schoolchildren in grade $\mathrm{V}(67.8 \%)$ in Tukamasea were examined (Fig.4).

There was no statistically difference in age group and sex among the registered and examined schoolchildren in the two villages (chi-square test with Yate correction, $\mathrm{p}>0.05$ ). No clinical signs of leprosy were found from schoolchildren in the two villages during the survey.

Distribution of IgM antiPGL-I antibody titer in schoolchildren and community survey. As shown in Table 1, using the MLPA test on sera from 80 examined schoolchildren in Jenetaesa turned out to be
$17.6 \%$ positive and $82.4 \%$ were negative. Among those positive MLPA results, the titers of MLPA were $32(11.3 \%)$ and $64(6.3 \%)$. In the community survey out of 510 examined persons : $18.4 \%$ were positive and $81.6 \%$ were negative. Among those positive MLPA results, the titers of MLPA test were 32 $(14.7 \%), 64(3.1 \%), 128(0.2 \%)$ and $256(0.4 \%)$ respectively.

In the Tukamasea schoolchildren survey out of 44 examined schoolchildren : $40.9 \%$ were positive and $59.1 \%$ were negative. Among those positive MLPA results, the titers of MLPA were 32 (29.5\%), 64 (9.1\%) and $256(2.3 \%)$. In the community survey out of 1496 examined persons : $40.4 \%$ were positive and $59.6 \%$ were negative. Among those positive MLPA results, the titer of MLPA were 32 (21.9), 64 (15.7\%), 128 $(2.3 \%), 256(0.2 \%), 512(0.1 \%)$ and $1024(0.1 \%)$.

Comparing the seroprevalence between the schoolchildren survey and the community survey. The seroprevalence of schoolchildren in Jenetaesa was found to be $17.6 \%$ ( 15 out of 80 schoolchildren were MLPA positive). As it is not feasible to collect sera for MLPA test from all examined population, we randomized to collect sera in the community survey. The seroprevalence of the population in Jenetaesa was found to be $18.4 \%$ ( 94 out of 510 persons were MLPA positive).

No significantly difference in seroprevalence between the schoolchildren survey and the community survey (Fischer exact test, p >0.01) were found.

The seroprevalence of schoolchildren and population in Tukamasea were found to be significantly higher than in Jenetaesa (Fischer exact test, p < 0.01), statistically (Fig.5).

Table 1. Distribution of IgM- PGL-I antibody titer using MLPA test in schoolchildren and community survey in 1994

\begin{tabular}{c|cccc|crrr}
\hline \multirow{2}{*}{$\begin{array}{c}\text { MLPA } \\
\text { Titer }\end{array}$} & \multicolumn{3}{|c|}{ Jenetaesa Village } & \multicolumn{3}{c}{ Tukamasea Village } \\
\cline { 2 - 8 } & $\begin{array}{c}\text { Schoolchildren } \\
\text { Survey }\end{array}$ & $\%$ & $\begin{array}{c}\text { Community } \\
\text { Survey }\end{array}$ & $\%$ & $\begin{array}{c}\text { Schoolchildren } \\
\text { Survey }\end{array}$ & $\begin{array}{c}\text { Community } \\
\text { Survey }\end{array}$ & $\%$ \\
\hline Negative $^{*}$ & 66 & 82.4 & 416 & 81.6 & 26 & 59.1 & 892 & 59.6 \\
32 & 9 & 11.3 & 75 & 14.7 & 13 & 29.5 & 328 & 21.9 \\
64 & 5 & 6.3 & 16 & 3.1 & 4 & 9.1 & 235 & 15.7 \\
128 & 0 & 0.0 & 1 & 0.2 & 0 & 0.0 & 35 & 2.3 \\
256 & 0 & 0.0 & 2 & 0.4 & 1 & 2.3 & 0.2 \\
512 & 0 & 0.0 & 0 & 0.0 & 0 & 0.0 & 2 & 0.1 \\
1024 & 0 & 0.0 & 0 & 0.0 & 0 & 0.0 & 1 & 0.1 \\
\hline$*$
\end{tabular}

\footnotetext{
${ }^{*}$ ) Cut off of MLPA titer is 32
} 
The seroprevalence of the schoolchildren survey in Tukamasea was found to be $40.9 \%$ (18 out of 44 schoolchildren were MLPA positive), while in the

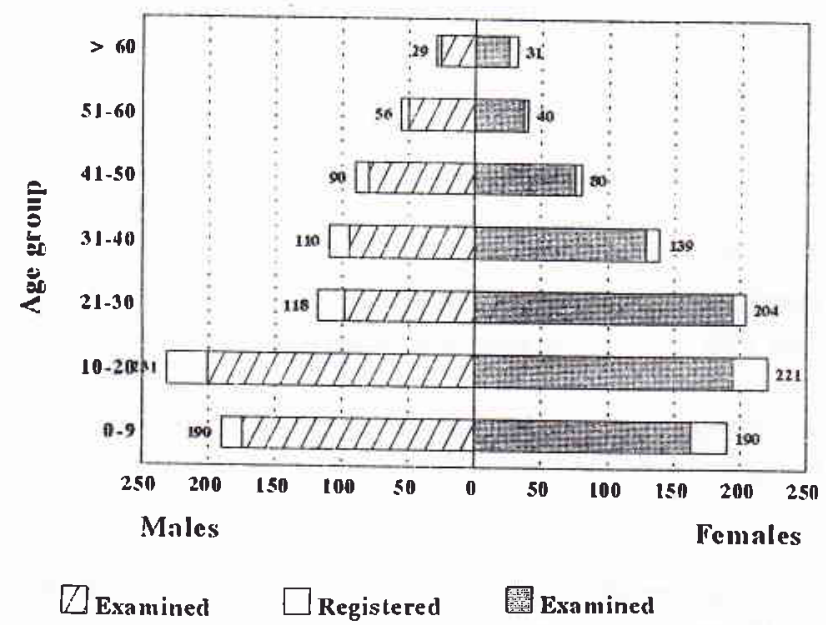

Difference in sex group among registered population and examined population is not significant (chi square test, $p>0.05$ )

Figure 1. Distribution of registered and examined population according to age and sex in Jenetaesa village, 1994

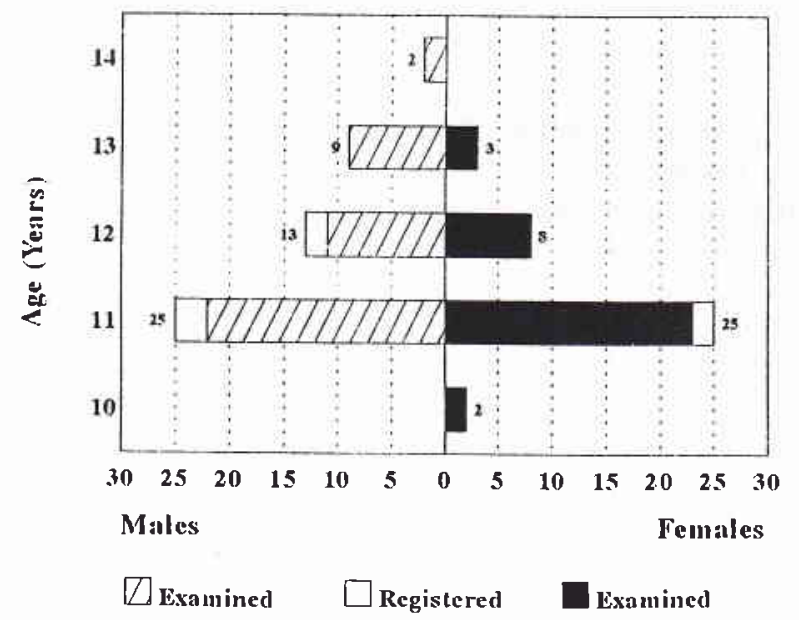

Difference in sex group among registered population and examined schoolchilren is not significant (chi square test, $p>0.05$ )

Figure 3. Distribution of registered and examined schoolchildren according to age and sex in Jenetaesa village, 1994 community survey it was found to be $40.4 \%$ (604 out of 1496 persons were MLPA positive).

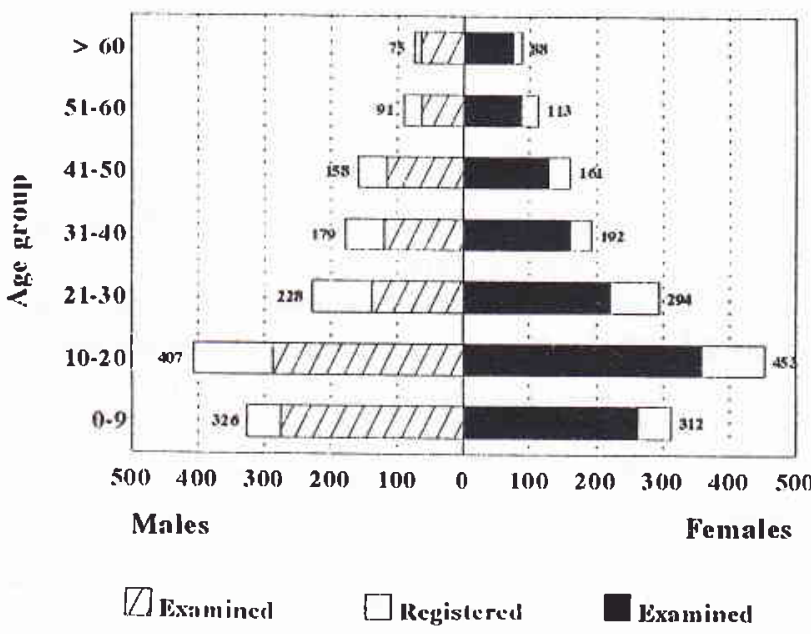

Difference in sex group among registered population and examined population is not significant (chi square test, $\mathrm{p}>0.05$ )

Figure 2. Distribution of registered and examined population according to age and sex in Tukamasea village, 1994

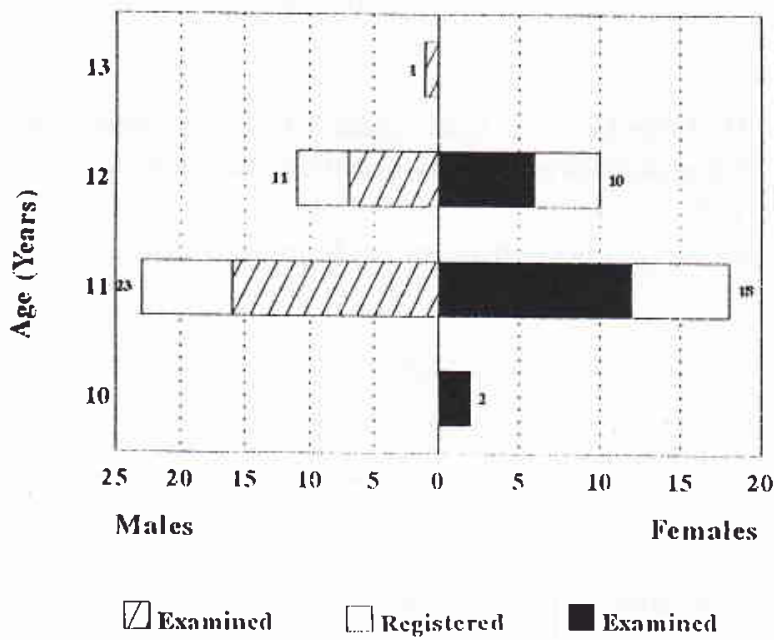

Difference in sex group among registered population and examined schoolchildren is not significant (chi square test, $p>0.05$ )

Figure 4. Distribution of registered and examined schoolchildren according to age and sex in Tukamasea village, 1994 


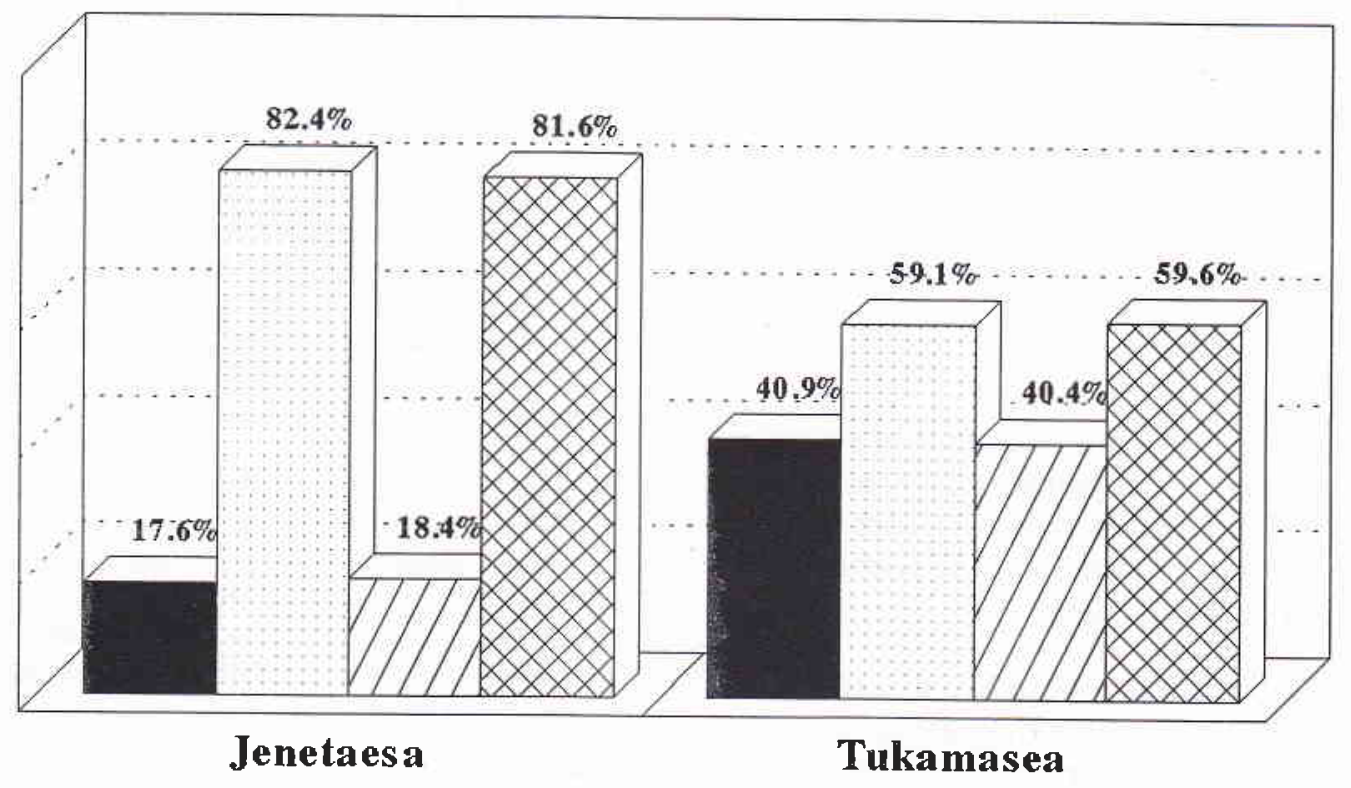

\section{School Positive $\quad$ School Negative $\square$ Community Positive $\otimes$ Community Negative}

Figure 5. Seroprevalence of schoolchildren survey and community survey in Jenetaesa and Tukamasea village, 1994

\section{DISCUSSION}

The pattern of leprosy transmission among the population is currently unclear. Evidence suggests that most of the new cases of leprosy found are not due to close contact with leprosy patients. However, it was proved that the chance of developing this disease is far more bigger in the households where patients with multibacillary (MB) leprosy is present. We have increasing evidence to show that a considerable number of inhabitants have been infected with leprosy. ${ }^{8}$ Most of them have no history of being subjected to direct contact with leprosy patients, suggesting that the source of infection of leprosy bacilli is not limited to untreated leprosy patients.

Using polymerase chain reaction (PCR) to detect DNA $M$. leprae from nasal swab specimens, demonstrated that about $8.0 \%$ of the general inhabitants in endemic villages in South Sulawesi, Indonesia, carry $M$. leprae on the surface of their nasal mucosa. ${ }^{4}$ These epidemiological observation suggest the possibility that rather strong infectivity of leprosy bacilli and widely distribution of $M$. leprae in the environment of the endemic areas play an important role in the continual high incidence of leprosy in an area.

Several serological tests have been developed over the past years to detect leprosy infection. ${ }^{14}$ The results, however, are still not satisfying. Currently, interest in serodiagnosis has been revived by the invention of a serological test based on a supposedly $M$. leprae specific antigenic determinants. 15,16

IgM anti PGL-I antibodies, specifically directed against the trisaccharide epitope, have been demonstrated in the sera of leprosy patients. ${ }^{17}$ as well as its parallel relationship with the bacterial index. ${ }^{18,19}$ 
Furthermore, a seroepidemiological study of $M$. leprae infection using MLPA and ELISA to detect IgM anti PGL-I antibodies in inhabitants of a leprosy endemic village in South Sulawesi, Indonesia has also been reported. ${ }^{11}$ The validity of this suggestion, unfortunately, has never been tested in schoolchildren which may be representative in a population for the determination of the magnitude of seroprevalence in leprosy endemic areas.

In this study, to determine the magnitude of infection among a population, we examined schoolchildren in two villages, which differ in seroprevalence and we compared the findings by examining the population in the same leprosy endemic village.

We propose to validate this approach of assessment of the leprosy problem through extrapolation of seropositivity rates in schoolchildren in other areas, both in Indonesia and beyond.

Although, the seropositivity rates in children is representative of seropositivity rates in populations, further information is needed to determine the sources of transmission in human. The detection of DNA $M$. leprae by PCR from nasal swabs specimens in schoolchildren and populations is still in progress.

\section{Acknowledgements}

The author would like to thank Drs. Paul R. Klatser, Stella van Beers and Shinzo Izumi for critical reading of the manuscript.

The author would also like to express his gratitute to the Head of the Regional Office of the Ministry of Health, Republic of Indonesia in South Sulawesi and the Leprosy officer of the Ministry of Health in the province of South Sulawesi for their cooperation. He is indebted to all people in the villages who voluntarily cooperated in this study.

The financial support of The Netherlands Leprosy Relief Association (NSL) and Pfeizer Health Research Foundation of Japan is greatly appreciated.

Also, thanks to Dr. Takafumi Hayashi, Director General of Toyama YUAI Hospital, for his financial support through the Japan Indonesia Medical Association of YUAI Hospital (JIMA).

\section{REFERENCES}

1. Noorden SK, Lopez Bravo L, Sundaresan TK. Estimated number of leprosy cases in the world. WHO Bull 1992; 70: 707-10.
2. Hartskeerl RA, De Wit MYL, Klatser PR. Polymerase chain reaction for the detection of $M$. leprae. J Gen Microbiol 1989; 135: 2357-64.

3. Hatta M. Application of polymerase chain reaction for detection of Mycobacterium leprae DNA in nasal swab specimens from untreated leprosy patients. Proceed. 2nd Asian Pacific Conference on Medical Genetics and Eijkman Symposium on the Molecular Biol Dis. 1995; Jakarta : 127.

4. Hatta M, van Beers SM, Madjid B, Achmad D, de Wit MYL, Klatser PR. Distribution and persistence of Mycobacterium leprae nasal carriage among a population in which leprosy is endemic in Indonesia. Trans R Soc Trop Med Hyg 1995; 89: 381-5.

5. Izumi S, Sugiyama K, Fujiwara T, Hunter SW, Brennan PJ. Isolation of Mycobacterium leprae specific glycolipid antigen, phenolic glycolipid-I from formalin fixed human lepromatous liver. J Clin Microbiol 1985; 22: 680-2.

6. Izumi S, Fujiwara T, Ikeda M, Nishimura Y, Sugiyama K, Kawat su K. Novel gelatin particle agglutination test for serodiagnosis of leprosy in the field. J Clin Microbiol 1990; 28: 525-9.

7. Fine PEM. Problems in the collection and analysis of data in leprosy study. Lep Rev 1981; 52: 197-206.

8. Hatta M, Izumi S, Klatser PR. Evaluation of the Mycobacterium leprae particle agglutination (MLPA) test as tool in the epidemiology of leprosy in high prevalence village in South Sulawesi, Indonesia. Southeast Asian J Trop Med Pub Health 1995; 26: 631-5.

9. Godal T, Negassi S. Subclinical infection in leprosy. Br Med J 1973; 3: 557-9.

10. Hatta M, Izumi S, Kawatsu K, van Beers SM, Klatser PR. Distribution and persistence of antibody to phenolic glycolipid-I among individuals in an area in which leprosy is endemic. Am J Trop Med Hyg 1996; submitted for publication.

11. Izumi S, Hatta M, Kawatsu K, Matsuoka M. Seroepidemiological study of $M$. leprae infection in inhabitants of leprosy endemic village in South Sulawesi, Indonesia. Int J Leprosy 1995; 63: 650

12. Izumi S, Hatta M, Matsuoka M, Kawatsu K. Identification of leprosy infection using PGL-I antibody in population which leprosy endemic area, Indonesia (in Japanese). Jap J Leprosy 1996; 65: 50.

13. Ridley DS, Jopling WH. Classification of leprosy according to immunity : a five-group system. Int J Lepr 1966; 34 : 255-73.

14. Melsom R. Serodiagnosis of leprosy : the past, the present, and some prospect for the future. Int J Lepr 1983; 51: 235-52.

15. Brett SJ, Drapper P, Payne SN, Rees RJW. Serological activity of a characteristic phenolic glycolipid from Mycobacterium leprae in sera from patients with leprosy and tuberculosis. Clin Exp Immunol 1983; 52: 271-9.

16. Klatser PR, de Wit MYL, Kolk AH. An ELISA-inhibition test using monoclonal antibody for serology of leprosy. Clin Exp Immunol 1985; 62: 468-73.

17. Brett SJ, Payne SN, Gigg J, Burgess P, Gigg R. Use of synthetic glycoconjugates containing Mycobacterium leprae specific and immunodominant epitope of phenolic glycolipid I in the serology of leprosy. Clin Exp Immunol 1986; 64: 476-83. 
18. Levis WR, Meeker HC, Schuller-Levis G, Sersen E, Schwerer B. IgM and IgG antibodies to phenolic glycolipid I from Mycobacterium leprae in leprosy; insight into patient monitoring, erythema nodosum leprosum, and bacillary persistence. J Invest Dermatol 1986; 86: 529-34.
19. Schewerer B, Meeker HC, Sersen E, Levis WR. Ig M antibodies against phenolic glycolipid I from Mycobacterium leprae in leprosy sera: relationship to bacterial index and erythema nodosum leprosum. Acta Leprol (Geneva) 1984; 2: 395-402. 